\title{
The Use of Preemergence Herbicides for Weed Control Around Young Coffee Seedlings
}

\author{
Jaime González Ibaiñez ${ }^{1}$
}

\section{INTRODUCTION}

Weed control can be a serious problem in the coffee nursery where coffee seedlings are grown for a year, or a year and a half, after completing the first stage. The first stage of control consists in proper fumigation of the soil and then seeding. Previous work has shown that it is possible to sow coffee seed directly in plastic bags $(1)^{2}$, and in the seedbed (2), and grow healthy seedlings up to a certain age with excellent weed control. This freedom from weeds can last 90 days.

The most difficult part of weed control arises in the nursery, when coffee has reached about 5 or 6 inches in height in the bag. At this stage removal of weeds is physically injurious to coffee seedlings and weeds compete with coffee seedlings for water and nutrients. This endangers the life of the seedling by shading it partly or completely, thus not allowing it to develop. The cost of weed control is large during this long period of developing seedlings into plants ready for field transplanting.

With the many herbicides now available it was believed possible to find procedures that would permit weed-free, extended growth of coffee plants in plastic bags. Therefore, several preemergence herbicides were investigated to determine the minimum safety dosage for coffee seedlings with the maximum of weed control.

\section{REVIEW OF LITERATURE}

Investigations of weed control in coffee-growing have been conducted since 1945 . The coffee tree is very sensitive to many chemicals used in weed control $(3,4,5)$. Symptoms of toxicity have been described and reported for 2,4-D materials in Arabica coffee. Symptoms of damage from T.C.A. $(3,6)$ have also been reported. Damage from Monuron $(3,6)$ has been described. Recommendations exist in Hawaii $(\gamma)$ for preweed-emergence control with fortified oil emulsions for freshly perpared nursery beds (7). More recent work has been carried out with Amitrole to control persistent grass weeds, and slight clorophyll inhibition has been observed in young coffee trees following Amitrole sprays (7).

1 Assistant Chemist, Agricultural Experiment Station, University of Puerto Rico, Río Piedras, P.R. The author wishes to express his gratitude to Frederick L. Wellman for assistance and cooperation during the publishing of this paper.

${ }^{2}$ Italic numbers in parentheses refer to Literature Cited, pp. 30-1. 
Not much work has been done in Puerto Rico on the use of preemergence herbicides for controlling weeds in young coffee seedlings in the nursery. Wellman (2), recommended the use of Dinitro (Dow General Weed Killer) at the rate of 1 gallon in 100 gallons of water, per acre, of nursery seedbeds.

\section{PROCEDURE}

This investigation involved the use of black plastic bags $53 / 4$ inches in diameter with side perforations. Each of these was filled with 13 pounds of soil that was the greenhouse potting mixture, sifted through a $1 / 2 \times 1 / 2$-inch screen mesh. A total of 280 coffee seedlings, Coffea arabica L., variety, bourbon choussy, that were 5 months old were brought to Rio Piedras from the Adjuntas region and planted in the bags on June 16, 1961. They were left in the greenhouse for 1 month to become well established.

More soil selected from a field with a heavy stand of Echinocloa colonum (L.) Link, jungle rice, was brought to Río Piedras. Here, the soil was sifted through a standard 20-gage soil sieve to separate the $E$. colonum seed. The seed were sown on the top of the bags planted with coffee seedlings at the rate of $150 \mathrm{gm}$. per bag to insure a good supply of grass weed-seed. The soil surfaces in the bag were treated with herbicides following the sowing of the grass weed-seed.

The surface of a seedling bag was measured and was found to consist of about 0.25 square foot. To each such surface a chemical was applied in a water solution. This was made from freshly prepared stock solution or emulsion, so that the final dilution would contain the required per-acre rate. The application was made with a pipet, covering the entire surface of each bag twice. The whole operation of treating the bags was performed July 18 to $21,1961$.

The preemergence herbicides (8) used in this experiment were: Monuron, at rates of 2,4 , and 8 pounds per acre; Diuron, at rates of 2,4 , and 8 pounds per acre; Neburon, at rates of 4,8 , and 16 pounds per acre; Simazine, at rates of 2,4 , and 8 pounds per acre; Atrazine, at rates of 2,4 , and 8 pounds per acre; Amizine, at rates of 2,4, and 8 pounds per acre; Fenac, at rates of 2,4, and 8 pounds per acre; Silvex, at rates of 2,4 , and 8 pounds per acre; DNBP, at rates of 4,8 , and 16 pounds per acre; and an untreated check. Ten replicates of each treatment were used, with one coffee seedling per bag.

Data on the growth of the coffee seedlings were taken at 15-day intervals for the 5-month duration of the experiment, using a standard 1-foot rule. Every 30 days, where required, the surface of the bags was weeded by hand, and the weights of the weeds were recorded in grams. This operation was performed without digging the soil in any plastic bag. Data on the numbers and weights of weeds were recorded for the duration of the experiment, 
TABLE 1.-Influence of cerlain herbicide treatments applied to weed-infested soil around coffee seedlings set in plastic bags in the nursery

\begin{tabular}{|c|c|c|c|c|c|c|c|}
\hline & & & Coffee (av & (erages) & & Weeds & averages) \\
\hline & atment & & Growth & & & & \\
\hline & & Number & Inches & Grams & Grams & Number & Grams \\
\hline 1. Monuron & 2 lb./acre & 10 & 14.25 & 31.86 & 11.29 & 52.0 & 2.11 \\
\hline 2. Monuron & 4 lb./acre & $10^{1}$ & 14.03 & 32.19 & 10.86 & 37.2 & .34 \\
\hline 3. Monuron & 8 l.b/acre & $81,2,3$ & 7.90 & 15.10 & 5.80 & 30.7 & .18 \\
\hline 4. Diuron & 2 lb./acre & 10 & 11.75 & 26.08 & 10.53 & 41.4 & $2.62^{4}$ \\
\hline 5. Diuron & 4 lb./acre & 10 & 14.78 & 30.88 & 8.96 & 29.9 & .93 \\
\hline 6. Diuron & 8 lb./acre & $10^{5}$ & 13.58 & 28.67 & 9.34 & 29.9 & .13 \\
\hline 7. Neburon & $4 \mathrm{lb} . / \mathrm{acre}$ & $10^{5,5}$ & 15.33 & 36.90 & 12.16 & 119.3 & 20.24 \\
\hline 8. Neburon & $8 \mathrm{lb} . / \mathrm{acre}$ & $10^{6.6}$ & 14.88 & 33.83 & 10.28 & 88.9 & 16.42 \\
\hline 9. Neburon & $16 \mathrm{lb}$./acre & $10^{6,5}$ & 14.73 & 32.37 & 10.91 & 64.1 & $1.55^{4}$ \\
\hline 10. Simazine & $2 \mathrm{lb} . / \mathrm{acre}$ & 10 & 14.93 & 33.85 & 12.18 & 85.9 & $3.70^{4}$ \\
\hline 11. Simazine & 4 lb./acre & $10^{t,}$ & 14.10 & 30.39 & 11.18 & 84.0 & 5.564 \\
\hline 12. Simazine & $8 \mathrm{lb} . /$ acre & $10^{1,6}$ & 13.95 & 29.85 & 9.88 & 66.8 & 4.48 \\
\hline 13. Atrazine & 2 lb./acre & $10^{1,5}$ & 11.88 & 20.08 & 7.58 & 114.8 & 13.49 \\
\hline 14. Atrazine & 4 lb./acre & 101.6 & 10.33 & 18.33 & 6.60 & 67.3 & 2.08 \\
\hline 15. Atrazine & 8 lb./acre & $10^{5}$ & 11.00 & 21.15 & 7.11 & 53.8 & .77 \\
\hline 16. Amizine & $2 \mathrm{lb} . / \mathrm{acre}$ & $10^{5}$ & 15.50 & 31.65 & 12.64 & 104.8 & $10.05^{4}$ \\
\hline 17. Amizine & $4 \mathrm{lb}$./acre & $10^{5}$ & 14.20 & 32.16 & 12.25 & 101.2 & $12.96^{4}$ \\
\hline 18. Amizine & $8 \mathrm{lb} . /$ acre & $10^{5}$ & 12.25 & 27.69 & 10.74 & 52.3 & $3.55^{4}$ \\
\hline 19. Fenac & $2 \mathrm{lb} . / \mathrm{acre}$ & $10^{7}$ & 10.15 & 17.49 & 7.19 & 76.2 & 13.92 \\
\hline 20. Fenac & 4 lb./acre & $9^{2,7}$ & 5.68 & 7.70 & 2.60 & 47.6 & 1.63 \\
\hline 21. Fenac & $8 \mathrm{lb} . /$ acre & $5^{2,7}$ & 1.88 & 2.39 & 1.65 & 19.6 & 1.03 \\
\hline 22. Silvex & 2 lb./acre & $10^{1}, 7,3$ & 12.83 & 19.39 & 7.23 & 159.5 & 58.08 \\
\hline 23. Silvex & 4 lb./acre & $10^{1,7,3}$ & 11.78 & 22.31 & 7.36 & 128.3 & 34.73 \\
\hline 24. Silvex & $8 \mathrm{lb} . / \mathrm{acre}$ & $10^{1,7,3}$ & 10.88 & 18.22 & 6.57 & 96.8 & 21.69 \\
\hline 25. DNBP & $4 \mathrm{lb} . / \mathrm{acre}$ & $10^{7}$ & 7.95 & 14.72 & 6.09 & 163.9 & 101.59 \\
\hline 26. DNBP & $8 \mathrm{lb} . /$ acre & $10^{7}$ & 9.15 & 14.11 & 7.60 & 145.5 & 70.01 \\
\hline 27. DNBP & $16 \mathrm{lb} . / \mathrm{acre}$ & $10^{\circ}$ & 15.80 & 43.66 & 11.37 & 121.8 & 24.58 \\
\hline 28. Check & & 10 & 11.43 & 20.07 & 7.65 & 232.3 & 109.32 \\
\hline lalysis 0 & & & & & & & \\
\hline F value ${ }^{8}$ & & & $7.21^{* *}$ & $6.70 * *$ & $4.64^{* *}$ & $16.42^{* *}$ & $34.31^{* *}$ \\
\hline Standard er & & & 1.2177 & 3.4245 & 1.3108 & 12.2457 & 5.0825 \\
\hline
\end{tabular}

1 Chlorosis notable in some of the leaves.

2 In these cases 10 seedlings planted for each treatment; any number less due to killing from herbicide.

3 New leaves, since treatment, stunted, twisted, and frilled at margin with complete nechrosis and final defoliation.

- Best treatments from general standpoint; not only good herbicidal result, but least bad effect on coffee seedlings.

${ }^{5}$ New leaves, after 90 days, narrow; recovery after 120 days.

6 Stimulation of growth.

7 Malformed leaves and stunted at the end of the experiment. 8** Significant to the 1-percent level. 
along with a final recording of the height of the coffee seedlings and weight of tops and roots.

\section{RESULTS}

The results of the influence of certain herbicide treatments on weed-infested soil around coffee seedlings set in plastic bags in the nursery are shown in table 1.

\section{DISCUSSION}

\section{SUBSTITUTED UREAS}

The use of the herbicides Monuron, Diuron, and Neburon was investigated at different dosages. The purpose was to determine the necessary amount of the chemical that would eliminate the weeds with the least effect on coffee seedlings. The most soluble material was Monuron, and, at the rate of 4 pounds to the acre, it gave markedly good weed control. However, a distinct yellowing of the leaves and, in some cases, death of the plants was observed with the larger dose of 8 pounds per acre. This finding agrees with work done by Duthie (9). When he used 2 to 4 pounds of Monuron as a preemergence treatment on coffee, he secured striking results.

Chlorosis appeared with the larger dose at about 4 weeks after treatment, in the upper part of the seedlings, followed by death of three trees at the end of 5 weeks. The ones which survived grew poorly, and were stunted at all times. This agrees with the work done by Havis ( 8 ), who described Monuron damage as new leaves frilled at margin, twisted, and complete necrosis occurred, with final death of entire branches.

Diuron gave good weed control with no damage to the coffee seedlings, although a slight reduction in growth and weight of tops indicated stunting. At 4 pounds to the acre, coffee growth was increased. A higher dosage produced a severe stunting of the coffee plant as the length of time progressed.

Neburon, at 4 and 8 pounds to the acre, did not stop coffee seedlings from being well-developed. However, it was not so good as a weed control until applied at the higher dose of 16 pounds per acre. There was good weed control with this chemical used at the rate of 16 pounds to the acre, and no detrimental effect on coffee plants was produced by the three doses. Apparently, even larger doses of Neburon should have been investigated, for a stimulation effect on coffee growth and weight of tops of the coffee seedlings under the larger dose of this treatment were observed.

\section{TRIAZINES}

Simazine and Atrazine gave good results as weed controls, particularly the more soluble Atrazine (10) at the higher dose of 8 pounds per acre. Atrazine produced a slight chlorosis, but the growth of coffee was excellent at 2 
and 4 pounds per acre. The larger doses of this chemical caused the formation of narrow apical leaves, but no chlorotic symptoms developed in these leaves. Simazine at the lower dose of 2 pounds to the acre resulted in healthy-looking coffee seedlings, but at the higher doses there was a reduction in coffee growth, weight of tops, and weight of roots. Simazine at the larger doses of 4 and 8 pounds produced chlorosis of coffee leaves in the lower part of the seedling.

\section{AMIZINE}

Control of weeds with the mixture of Amitrole and Simazine was fairly good. Growth of the coffee seedlings was excellent at the lowest rate of 2 pounds to the acre. At this rate weights of tops and roots were not affected by the chemical, but at the higher rates of 4 and 8 pounds per acre, a reduction in coffee growth, weight of tops, and weight of roots perhaps indicated a toxic effect on the coffee seedlings. A slight chlorophyll inhibition was found at 8 pounds per acre.

\section{FENAC}

When Fenac was employed, control of weeds was good for 3 months, but with a marked deleterious effect on the coffee seedlings. Their growth was poor and delayed. Plants under these treatments were notably green, but distorted and twisted leaves were observed at every dosage used. This chemical caused curling of the leaves which were well-expanded at the time of treatment. The symptoms appeared 5 weeks after application. A severe restriction of the leaf lamina was commonplace. The highest dose of this chemical produced the poorest growth. Within 90 days from treatment five seedlings had died. These treatments caused the same symptoms of malformation in the seedlings as the 2,4-D malformation described by Havis ( 3 ) and Orsenigo et al. (4) in coffee seedlings.

\section{SILVEX}

Silvex produced symptoms of stunted growth on coffee at every dosage. The seedlings also grew at all times, but with malformations in each leaf that appeared after treatment. New leaves were twisted and dwarfed. Severity of symptoms increased with time. There was extreme chlorosis, and this increased with time, but no defoliation occurred. The herbicidal activity of this was short, as it only lasted for 30 days.

DNBP

Coffee plants that were treated with DNBP were the tallest plants at the highest application rate of 16 pounds per acre. However, weed control was 
poor at any dose used. Also, at every rate used, DNBP caused a bleaching of the lower leaves, without defoliation.

\section{UNTREATED CHECKS}

The untreated checks were the weediest at all times and the plants were poorly developed at the end of the experiment. However, no chlorosis was observed.

\section{SUMMARY}

The preemergence herbicides Monuron, Diuron, Neburon, Simazine, Atrazine, Amizine, Fenac, Silvex, and DNBP were tested each at three dosages on the surface of soil planted to young coffee seedlings in plastic bags. In general, the best weed control was obtained by using Diuron at the rate of 2 pounds per acre, Neburon at the rate of 16 pounds per acre, Simazine at the rate of 2 pounds per acre, and Amizine at the rates of 2, 4, and 8 pounds per acre.

Monuron at 8 pounds per acre caused severe stunting of coffee seedlings and the death of some. Root weight was greatly reduced. Diuron and Atrazine both tended to produce good seedling appearance, but reduced root weight. Fenac and Silvex caused malformed and stunted leaves in surviving coffee seedlings, and DNBP reduced coffee seedling vigor. Untreated checks grew poorly, and were the weediest at all times.

\section{RESUMEN}

Se probaron los herbicidas pregerminativos, Monuron, Diuron, Neburon, Simazine, Atrazine, Amizine, Fenac, Silvex, y Dinitro (DNBP) a tres concentraciones distintas cada uno, en cafetos jóvenes sembrados en bolsas plásticas. En general, los mejores resultados se obtuvieron con el uso de Diuron a razón de 2 libras por cuerda, Neburon a razón de 16 libras por cuerda, Simazine a razón de 2 libras por cuerda y Amizine a razón de 2, 4, y 8 libras por cuerda.

El Monuron a razón de 8 libras por cuerda inhibió severamente el desarrollo de las plántulas y causó la muerte de algunas, además, el peso de las raíces se redujo grandemente. Tanto el Diuron como el Atrazine mejoraron la apariencia de las plántulas, pero también redujeron el peso de las raíces. El Fenac y el Silvex deformaron e impidieron el desarrollo de las hojas en las plántulas que sobrevivieron; y el Dinitro redujo el vigor de éstas. Las plántulas que no recibieron tratamiento no se desarrollaron normalmente, y sufrieron grandemente de la competencia de los yerbajos.

\section{LITERATURE CITED}

1. Cibes, H. R., and González Ibáñez, J., unpublished data, 1961.

2. Wellman, F. L., Recomendaciones para Mejorar el Cultivo del Café en Puerto Rico, Univ. P.R. Agr. Expt. Sta. B. 163 69-70, Oct. 1960. 
3. Havis, J. R., Damage to coffee caused by herbicides, Turrialba J. 2 170, 1952.

4. Orsenigo, J. R., Segall, R. H., Smith, Ora, and Wellman, F. L., Systemic foliage distortions in coffee attributed to 2,4-D, Turrialba J. 3 100, 1953.

5. Robinson, J. B. D., Second progress report on chemical control of weeds in coffee, B. Coffee Bd. Kenya, 20 151, 1955.

6. Fleming, S. D., The role of herbicides in East African agriculture, 1st E. Afr. Herb. Conf., 1957, Summary, E. Afr. Agr. J. 23 10, 1957.

7. Robinson, J. B. D., Chemical weed control in coffee; advances in coffee production technology, Coffee \& Tea, India, b. 4081 103, 1958.

8. Shaw, W. C., Report of the terminology committee, WSA, Weeds 8 487-521, 1960.

9. Duthie, D. W., The role of herbicides in East African agriculture, 1st E. Afr. Herbicide Conf., 1957, Summary E. Afr. Agr. J. 23 9, 1957.

10. Crafts, A. S., The Chemistry and Mode of Action of Herbicides; Interscience Publishers, New York, N.Y. and London, England, p. 109, 1961. 